\author{
"This is an Accepted Manuscript of an article published by Taylor \\ \& Francis in Journal of Sustainable Tourism on 20/10/2017, \\ available online: \\ http://www.tandfonline.com/doi/full/10.1080/09669582.2017.138712 \\ 1."
}

\title{
Have Australia's tourism strategies incorporated climate change?
}

\begin{abstract}
Tourism is widely acknowledged as a key contributor to climate change, but it remains unclear how the tourism industry has been planning for climate change in practice. This paper conducts the most comprehensive critical review of Australia's tourism policy and planning documents to date. The paper explores the complex challenges posed by climate change to tourism and how tourism policy has been adapting over a 15-year period. Drawing on a longitudinal dataset of 477 Australian tourism policy and planning documents at the national, state, regional and local level, this research analyses the strategic discourse on climate change using content analysis and bibliometrics. The findings reveal opportunities, challenges and strategies for the tourism industry to contribute to the sustainable management of climate change. Opportunities include developing more "green” products, while strategies include establishing and/or participating in collaborative climate change schemes and strengthening dialogue surrounding climate change to aid the implementation of sustainable practices. Future research should consider the broader policymaking environment, such as the stakeholders, power and interest dynamics when analysing tourism strategies in relation to climate change.
\end{abstract}




\section{Have Australia's tourism strategies incorporated climate change?}

\section{Introduction}

There is no more pressing issue in the 21st century than climate change (Goklany, 2003). As a multiscale and multisectoral problem, climate change response requires strong multilateral cross-institutional policies, as well as action at the individual and business level (Davoudi, Crawford, \& Mehmood, 2009). The signing of the Paris Climate Change Agreement in 2016 by 196 countries strengthened the ambitions of nations to reduce greenhouse gas emissions. While its predecessor, the Kyoto Protocol, was fixated on mitigation, the Paris Climate Change Agreement propounded adaptation and resilience measures (Scott, Hall, \& Gössling, 2016). Since 2011, there has been a decrease in global carbon dioxide emissions, largely the result of economic downturn, an increase in energy efficiency and an explosive policy drive in the renewable energy sector (Peters et al., 2017). Yet, for global emissions reduction targets to be realised, continued policy development and implementation is vital and lessons must be taken from policy history.

While often cited as a significant contributor to climate change, the tourism industry has an opportunity to play an important role in reducing global emissions through national policy responses (Scott \& Becken, 2010). As climate change will impact on tourism destinations, there is a critical need for the tourism sector to adapt, minimise risk and capitalise on new opportunities (Rosselló-Nadal, 2014). Nevertheless, the literature generally argues that the tourism industry is underprepared for climate change. There is a need for leadership in the sector to facilitate policy innovation, climate change risk assessment and resilience as a vital part of the global shift to a low carbon economy (Scott et al., 2016). Scott et al. (2016) argue that the tourism sector needs to go beyond emission modelling and forecasting; instead it should consider business and destination adaptation and mitigation strategies.

To date, the tourism literature on climate change has focused primarily on assessing the sector's impact on climate change through its contribution to emissions (see Becken, 2002; Dwyer, Forsyth, Spurr, \& Hoque, 2010; Gössling \& Hall, 2008; Gössling, 2013; Perch-Nielson, Sesartic, \& Stucki, 2010). As noted by Becken (2013), the literature tends to raise problems, rather than provide solutions or assess policy and practice initiatives, with a very few exceptions (e.g. Gössling, 2010; Becken \& Hay, 2013). Policy analysis is a tool that can provide insight into whether the tourism sector is able to adapt, which is critical for addressing 
climate change issues. Policies are decisions or actions that reflect the position of the public authority on an issue (Hall \& Jenkins, 1995). Exploring climate change policies in tourism is critical, largely due to the prevalence of blame avoidance in policy development. Howlett (2014) suggests conservative governments that do not favour strong climate change mitigation policies avoid political risk by adopting weak policy positions. Therefore, the prevalence and implementation of policies is related to the timing of policy interventions, as they are influenced by factors such as changes in government and political stance (Howlett, 2014; Moyle, McLennan, Ruhanen, \& Weiler, 2014).

Consequently, this research explores tourism climate change discourse in 477 Australian tourism policy documents across a 15-year period. Content analysis and bibliometrics are combined to provide rich insights into the shifts in strategic discourse that have shaped climate change policy innovation and development. This is the most comprehensive and extensive analysis of tourism climate change policy discourse to date, offering a longitudinal study and an historical perspective on how climate change has shaped Australia's tourism policy.

\section{Tourism climate change policy in Australia}

Climate change came onto the Australian political agenda in the late 1980s, but federal approaches to the issue have been varied and inconsistent, with a history of indecisive policies, as result of shifting political spectrums at the federal government level (UNWTO, 2014; Talberg, Hui, \& Loynes, 2016; Taberner \& Zorzetto, 2014). Australia’s climate change policy was first established in a report titled Our Country, Our Future released by the Hawke Government in 1989. At the time, Australia was perceived as a global leader and climate change advocate (Bulkeley, 2000). However, it took more than a decade for a state-level climate change strategy to be released in 2003 by the Western Australian (WA) Government (Pforr, 2015). Critics of the WA climate change strategy argue that the document was more a statement of intent than a plan for action (Mercer \& Marden, 2006; Phillips \& Kerr, 2005). It was followed by similar policy rhetoric that did not transcend into practice by other states and territories in Australia (Crowley \& Coffey, 2007).

A detailed analysis of Australia's federal response to climate change is discussed in Chapter 7 of the UNWTO (2014) report Responding to Climate Change: Tourism Initiatives in Asia and the Pacific. The report notes that generally the federal policies relating to climate change have focused on mitigation rather than adaptation. McMahon and Phillimore (2013) argued that 
many Australian policy documents with sustainability objectives originate under more socialist-leaning state or federal Labor governments and that incoming conservative governments tend to abandon or alter such plans. Yet, Pforr and Brueckner (2012) noted that Labor governments tend to be heavy on rhetoric, with a greater gap between policy and action. Consequently, the climate policies of the two major parties (the Australian Labor Party and the Liberal Party of Australia) over the last three decades have been erratic, despite climate change remaining an important election issue (Talberg et al., 2016).

The Australian Constitution grants state governments' power and control over certain issues, such as schools, hospitals, conservation, the environment, roads, railways and public transport, public works, industrial relations, community services, sport and recreation, consumer affairs, police, prisons and emergency services (Parliament of NSW, 2017). As such, various aspects of climate change fall under state jurisdiction, which has seen a number of Australian states develop their own renewable energy and emissions targets, climate strategies and policies. Consequently, state policies play an important role in Australia's climate change response. For example, New South Wales introduced the world's first mandatory emissions trading scheme, the Greenhouse Gas Abatement Scheme, although the scheme ceased when the Australian Government's carbon pricing scheme was introduced in 2012, to avoid duplication (Taberner \& Zorzetto, 2014). Soon after, Australia was the first nation to withdraw federal action on climate change by repealing the carbon price mechanism (Talberg et al., 2016), demonstrating the complexity of maintaining consistency in climate change action.

Turton et al. (2010) acknowledge that Australia is extremely exposed to the risks of climate change. While there has been substantial research into the effects of climate change in Australia, including some in the tourism context, there is less evidence that research is translating into policy and action (Buys, Miller, \& van Megen, 2012). The assessment by Turton et al. (2010) that Australian tourism stakeholders have a limited understanding of climate change adaptation is consistent with broader perspectives of tourism more generally (Scott \& Becken, 2010). Likewise, noting that tourism is likely to be directly impacted by climate change, Forsyth, Dwyer and Spurr (2007) summarise some broad international and national climate change policies that have been, and could be, implemented to address climate change in Australia, concluding that there is a need for the tourism sector to take greater initiative and action to mitigate and adapt to the impacts of climate change.

As Buultjens, White and Willacy (2007) point out, the Sustainable Tourism Cooperative 
Research Centre (STCRC) provided some leadership for the tourism sector's response to climate change by developing research, tools and solutions to enable action. This included the establishment of a national Climate Change Steering Committee and Advisory Group, the development of a Carbon Footprint for Tourism, a National Carbon Calculator and a Tourism Sustainability Portal. Yet the STCRC ceased to exist in June 2010, with Ruhanen and Shakeela (2013) finding soon after that the Australian tourism industry is unresponsive to climate change and operating as "business as usual" with a short-term outlook, despite climate change being perceived of high importance for the industry. Most tourism representatives interviewed did not see evidence that climate change affected the industry, nor the necessity for climate change response. Indeed, respondents noted that the tourism industry is largely relying on, and waiting for, government intervention and leadership on climate change.

Morrison and Pickering (2013) suggest the reliance on government action stems from a lack of knowledge and resources to appropriately plan for climate change, calling for a more collaborative approach between stakeholders. Yet, government-led approaches are largely dependent on political positions, which tend to alter with changes in government. The constant swings in federal government climate change policy have created a challenging environment with uncertainty surrounding the issue. This has limited the tourism sector's response, resulting in little emphasis on climate change in national-level tourism strategies (UNWTO, 2014). The UNWTO (2014) report concluded that Australia's national level tourism response to climate change has focused on minimal mitigation policies that have "overshadowed attention to adaptation ... [and the] lack of effective adaptation measures is unhelpful for tourism” (p. 94).

Broader research suggests that Australia's tourism policy and planning does incorporate sustainability concepts. From the 2000s, a new wave of strategic tourism plans emerged in Australia that focused on the adoption of sustainable development (Moyle et al., 2014). Further, McLennan, Becken and Watt (2016) found that tourism clusters in Australia have been adopting sustainability in practice as a tool to adapt to climate change, with various strategies being implemented by tourism sustainability leaders at the grassroots level. As climate change is a global-local issue, it is important to consider what is happening locally, especially as local governments and stakeholders are key actors in climate adaptation policy development (Vogel \& Henstra, 2015). Mukheibir, Kuruppu, Gero and Herriman (2013) argue that for climate change mitigation and adaptation to be effective, policy and planning must occur through multilevel governance. Thus, there is a need for policy analysis at all levels of government. 


\section{Tourism climate change policy analysis}

Broad climate change policy analysis undertaken by Wilson (2006) investigated changes in the discourse in UK government spatial planning documents between 2000 and 2005. Only half the plans acknowledged climate change as a factor. Given spatial planning is critical for urban, regional and coastal development, Wilson (2006) considered this to be low, arguing that climate change being primarily perceived as a set of specific threats, such as once-off or periodic events (e.g. flooding) or threatening specific assets (e.g. certain habitats, infrastructure or resources). However, Klint et al. (2012) acknowledge that there are few studies that explore the breadth of tourism climate change policies to inform adaptation and mitigation efforts.

Kaján and Saarinen (2013) provide a review of the academic literature on climate change and tourism until 2012, with a specific focus on adaptation. The authors identify key international forums such as the Djerba and Davos Declarations of Climate Change in Tourism (in 2003 and 2007, respectively) as triggers for policy response. They also point out that climate change is generally perceived as a hazard or potential threat to the tourism sector (Kaján \& Saarinen, 2013). Aligning with McKercher, Prideaux, Cheung and Law (2010), their review found that the Davos Declaration drew attention to the issue of adaptation, with mitigation a previous focus in both practice and scholarly discourse. Adaptation, a much more recent phenomenon, began to enter the literature from 2006 onwards (Kaján \& Saarinen 2013).

Shakeela and Becken (2015) mapped climate change risk perceptions among tourism practitioners in the Maldives, a region that is extremely exposed to the impacts of climate change and has a high economic dependence on tourism. Extreme events amplified locals' perceptions of the risk of climate change, in line with extant literature (Adger, Arnell, \& Tompkins, 2005). However, Shakeela and Becken (2015) also discovered that risk perception was heightened by the experiences of tourists who had witnessed the impacts of climate change (such as beach erosion) and the action (or inaction) of government. Climate change (mitigation or adaptation) was also not perceived as compatible with the island escape agenda of the Maldives as a tourism destination, resulting in the tendency of tourism practitioners to underplay climate change risks (Shakeela \& Becken, 2015).

The prevalence, nature and adoption of climate change policy in tourism strategies has not been clearly and systematically established, and this is an area of research that urgently needs to be addressed. As the UNWTO (2014) report acknowledges: "Despite the importance of the relationship between climate change policy and the response of the industry, academic research 
on the topic is still sparse” (p. 87). Addressing this gap is of high importance, particularly in an Australian context where distance necessitates long-haul carbon-intensive travel. The current studies considering tourism climate change policy offer vignettes into the strategic discourse, but fail to undertake longitudinal and multilevel analysis. A multilevel government analysis is critical given the tiered government system in Australia. Consequently, the following analysis of 477 national, state, regional and local level policy documents over a 15year period offers a unique perspective on the Australia tourism climate change policy landscape and is useful for identifying research gaps and opportunities for policy development.

\section{Method}

To capture the strategic discourse relating to climate change in Australia's tourism policy and planning documents, a comprehensive database of Australian national, state, regional and local level tourism strategic planning documents was obtained. At the time of analysis, the database contained 477 documents from between 2000 to 2014 (a 15-year policy period). Initially collected until 2011, the database has been analysed by Ruhanen, McLennan and Moyle (2013) and Moyle, McLennan, Ruhanen and Weiler (2014); however, these studies were focused on sustainability, rather than climate change. The database has been regularly updated since 2011; the latest update was in 2015, with strategies collected to the end of 2014. The collection and updating process was extensive and involved desktop auditing of Australian tourism strategic plans at all levels of government and policymaking (local, regional, state and national).

The sampling strategy for compilation and updating of the database involved Google keyword searches using the words "tourism” combined with "strategy" or "plan” or "policy” selecting only Australian results. To obtain a cross-section of relevant strategies, a sampling framework of all the state, regional and local tourism areas in Australia was developed. Using the sampling framework, the names of all these areas were also included as key search words in combination with those listed above to ensure comprehensive inclusion of tourism strategies and plans from all areas and levels of planning. To increase coverage across the sample frame, where strategies were missing for a particular area or level of government, email contact was made with representative organisations in the region to obtain any relevant tourism planning documents.

Identified documents were filed as Adobe PDF documents, with those only available in MS Word format being converted to Adobe PDF. If multiple strategies were obtained for a particular area or level of government, all strategies were included (e.g. if a strategy was 
released in 2008 and updated in 2012, both were included). If a date of publication was not explicitly stated, the strategy date of the document was set to the first year of the planning period. Tourism strategies and plans produced by tourism agencies (e.g. Brisbane Marketing), government (e.g. Department of Resources, Energy and Tourism [DRET]), statutory authorities (e.g. Tourism Australia) and industry bodies (e.g. Tourism and Transport Forum) were included in the database to provide balanced policy perspectives. The scope included peak industry bodies, as they are highly influential in the tourism policy space in the Australian context (Airey \& Ruhanen, 2013) and the policy process is about dynamic cooperation of the various policy actors (Dredge \& Jenkins, 2007).

The documents were filed in separate folders by year, level of government and state/territory. Each document was manually scrutinised by two independent researchers to ensure that they were within scope, using the criterion that the strategy or plan was produced by a tourism government agency or relevant association (Eton et al., 2013). Further, to ensure that tourism policy discourse was captured rather than generic or other-sector strategies, the strategic document was required to have either the term "tourism" in the title or to have the term "tourism" as a major component of the strategy or plan (defined as more than 20 occurrences within the text). This frequency statistics approach follows the approach of Angus, Rintel and Wiles (2013) for analysing large text data. If the strategy or plan did not satisfy these criteria it was deleted from the database as it was deemed not a "tourism” strategy or plan.

The documents were analysed using content analysis in MS Excel, a recognised and commonly employed tool in applied studies relating to tourism planning (Hall \& Valentin, 2005; Ruhanen, Breakey \& Robinson, 2012). The keyword “climate change” was searched throughout the 477 strategies using Adobe's PDF “Advanced Search” tool, resulting in 99 strategies being identified with climate change discourse (see list at Appendix A). This term was selected to ensure that the content collected was specifically discussing the issue of climate change and not strategies to cope with common environmental impacts, such as beach erosion and flood mitigation, which may not necessarily be associated with climate change. Whole paragraphs, sections or documents with climate change discourse were identified manually by two researchers and recorded in the MS Excel file. This process resulted in over 24,000 words being selected for content analysis.

The content analysis aimed to identify the key strategic issues and strategies discussed relating to climate change. As detailed codes and information on the strategies was required, the data 
reduction process involved manually reading and coding each emergent issue or concept into key themes, while retaining the detail (Van Dijk \& Kirk, 2007). This manual process took considerable time to reach literal replication with no new codes developed after the $63^{\text {rd }}$ document (Bradley, Curry, \& Devers, 2007). Regardless, even though saturation was reached, all 99 documents were coded. To enhance the reliability of the results, independent researchers cross-checked the coding, resulting in minor modification to the overarching codes (Hall \& Valentin, 2005). Bibliometric techniques, following Ruhanen, Weiler, Moyle and McLennan (2015) were undertaken in Stata v.14 to further assess the results of the content analysis, with qualitative quotes being selected from the strategies to exemplify and support the findings. For ease of reference to Appendix A, each strategy was allocated a number using the schema TCCS_n (Tourism Climate Change Strategy $1 \ldots n)$.

There are limitations of the method employed in this study. First, while several techniques were used to ensure a comprehensive coverage of Australia's tourism policy documents, the list may not be exhaustive as it may not capture internal planning documents or those only published in hard copy. Second, the documents used in this study only span a 15-year policy period. However, given that climate change only emerged as a key issue in the late 1980s, and the first Australian national-level tourism strategy was only released in 1992, this delimitation is not inappropriate (Ruhanen, Weiler, Moyle, \& McLennan, 2015). This study was constrained from collecting tourism policies and plans prior to 2000 as very few were made accessible on the internet (i.e. they were published in hard copy or had been removed from the web). Third, there was no attempt to weight the documents by organisation or relative importance as no population was available; instead, all publicly available Australian strategic planning documents were sought for inclusion. Leaving the data unweighted was considered important as it would provide evidence of organisations that are more actively involved in tourism planning and allow highlighted issues to emerge based on citation, rather than organisation. Finally, the study was restricted in that it only used the search term "climate change” and did not include others, such as disaster resilience, emissions reduction, global warming, greenhouse gas, beach erosion and flood mitigation. As noted earlier, this was to ensure that the discourse was focused specifically on the climate change debate and not strategies aimed at coping with more common environmental impacts that are not necessarily associated with climate change. However, by taking entire paragraphs and sections, rather than just sentences, this study ensured that wide-ranging discourse on climate change was included. 


\section{Results}

Of the 477 Australian tourism policy and planning documents, only 99 (21\%) mentioned climate change. Generally the strategies that mentioned climate change were produced at the local (36\%) and regional (33\%) level, followed by the state (19\%) and national (11\%) level. By comparison, the entire database was composed of strategies produced at the regional level (34\%), followed by the local (30\%), state (26\%) and national level (9\%), showing that the state level is underrepresented in the climate change discourse.

The 99 strategic documents that cited climate change as an issue contained a total of 24,768 words relating to climate change, or an average of 250 words each. Of the 99 strategies, 24 (24\%) contained above average (more than 250 words) discussion on climate change. These strategies were mainly produced at the national level (6), followed by strategies at the local, regional and state level in Queensland (4), New South Wales (4) and the Northern Territory (4). Notably, New South Wales did not produce a tourism climate change strategy at the state level throughout the entire 15-year period.

Bibliometric analysis revealed significantly more climate change strategies were produced during the years that the Australian Labor Party was in power at the federal level, with a peak in $2007\left(\chi^{2}(1, n=476)=27.99, \mathrm{p}<0.001\right.$; Figure 1$)$.

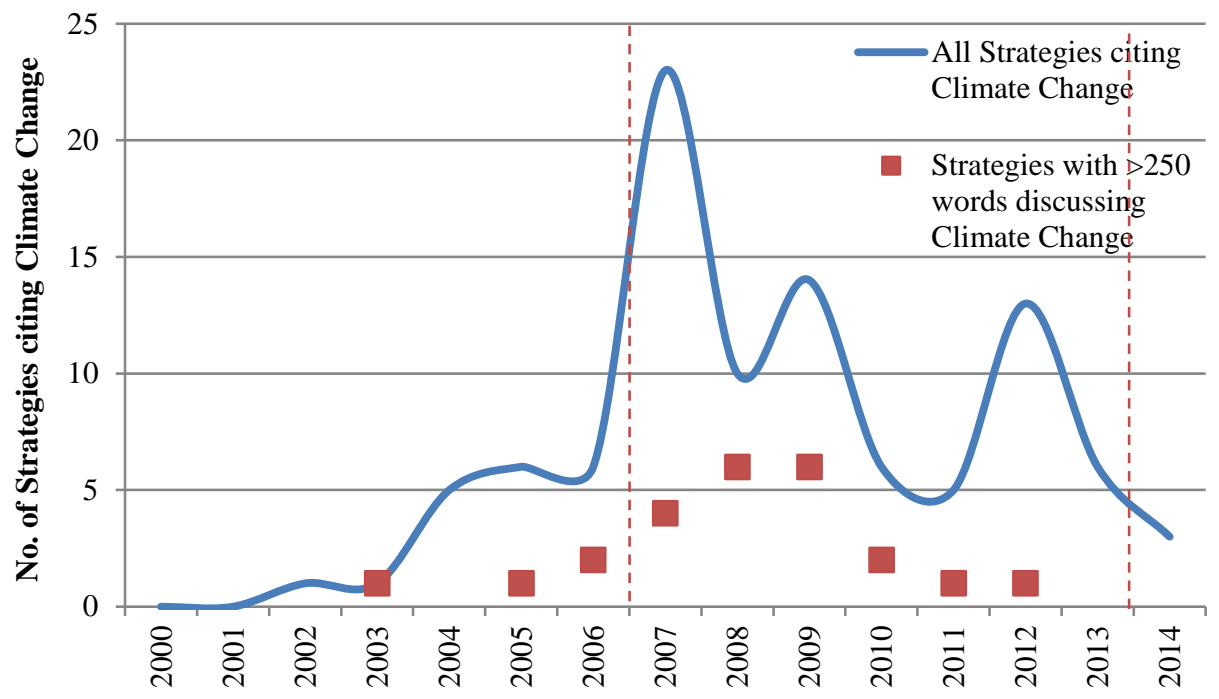

Figure 1. Number of strategies citing climate change by year of publication 
Queensland was significantly more likely than other states and territories to cite climate change $\left(\chi^{2}(1, n=476)=29.09, \mathrm{p}<0.001\right.$; Figure 2). Reflecting this, the organisation that produced the most climate change strategies was Tourism Queensland $(n=22)$, followed by Tourism Victoria $(n=6)$.

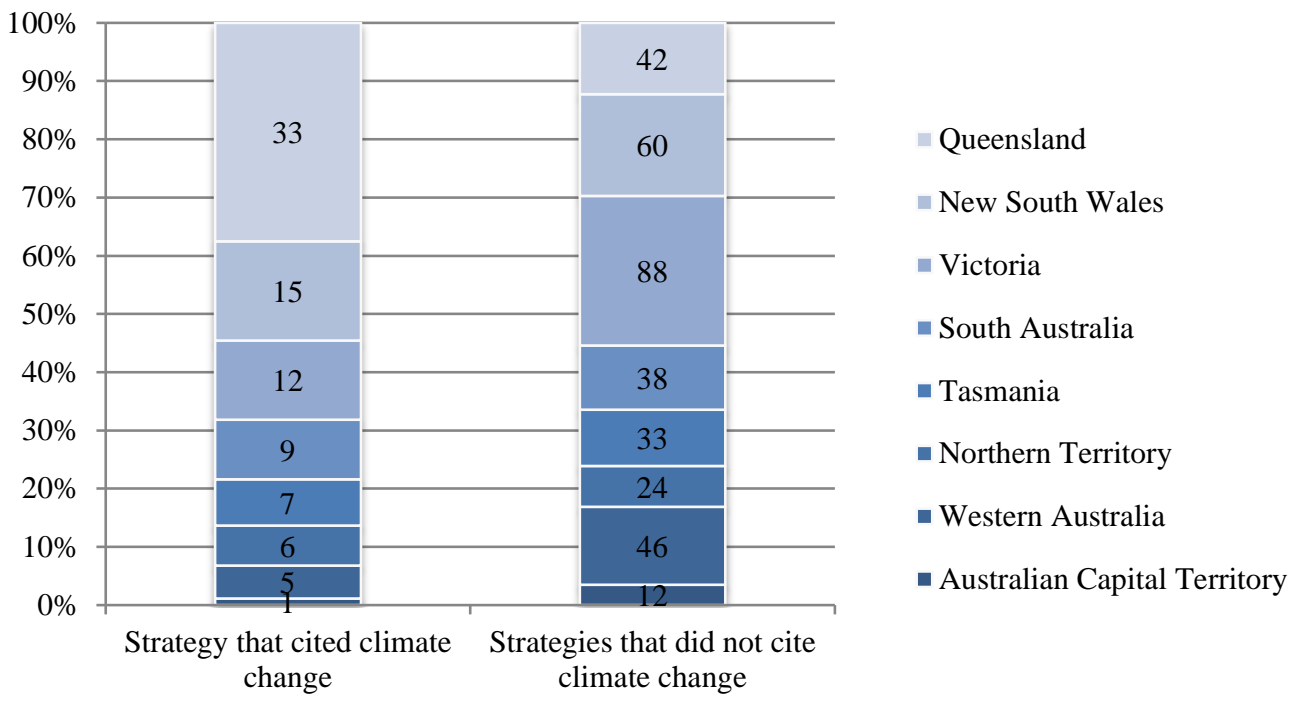

Figure 2. Number of strategies citing climate change by state of publication

Thematic analysis of the database identified five broad themes of climate change discourse: issue identification, opportunities, strategic needs, recommended strategies and actions, responding to climate change (e.g. actions taken and barriers/threats).

\section{Issue identification}

Sixty-eight of the 99 strategies had considerable discussion about whether climate change was an issue. Discourse analysis identified the "industry is keenly aware of the growing issue of climate change and its impact on business” (TCCS_5: The Business Events Industry Strategy Group, 2008, p. 49). Most strategies (60) simply identified climate change is an issue, threat, trend or challenge. Indeed, for 15 of the 99 strategies (15\%), this was the only mention of climate change, with no elaboration. Eleven of these 15 strategies were Destination Management Plans produced by Tourism Events Queensland and are a key example, simply citing climate change as a "global trend and influence", which inflated the number of climate change strategies produced by Queensland.

Thirty-seven strategies focused on forecasting or predicting climatic changes and the potential impacts on the tourism industry. The discourse relating to this concept concentrated on how 
global climate patterns may change, the likely increase in severe weather events, and the impact this would have on the environment, infrastructure and tourism. The strategies identified that there would be a loss of biodiversity, drought and reduced rainfall, water security problems, alterations in tides and currents, and declines in production from agriculture and forestry, as well as increased risks from high temperatures, sea level rise, storms, cyclones, coastal flooding, coral bleaching, bushfires, feral animals and weeds. In terms of the impacts on tourism, the strategies identified that climate change reduced the appeal of destinations and placed pressure on ecological sites, tourism attractions and infrastructure. This was considered a critical issue as "activities in the region are heavily dependent on the natural environment ..." (TCCS_92: Murraylands Tourism Partnerships, 2012, p. 2).

Eighteen strategies indicated that tourism is vulnerable to climate change, particularly transport infrastructure. Strategies suggested climate change had the potential to transform tourism, resulting in increased trip cancellations and rescheduling, itinerary changes, modifications to product marketing strategies, logistical operations, loss of attractions and damage to infrastructure. For example, TCCS_44 noted that "climate change impacts could jeopardise the entire \$5.1 billion Reef tourism industry” (Great Barrier Reef Marine Park Authority’s [GBRMPA], 2009, p. 9). As a result, these strategies argued that tourism would continue to face short- and long-term external shocks associated with climate change. Eight strategies discussed that the long-term impact of climate change was an emerging business risk and that it would impact on development and investment. Indeed, the impact of climate change was raised “...as a key industry threat” (TCCS_30: Queensland Government, 2006, p. 3).

The results revealed several sub-concepts focused on the potential impact of climate change on consumers. Thirteen strategies indicated that consumers were becoming increasingly focused on climate change and environmental sustainability when making purchasing decisions, with core markets educated about the impacts of climate change. Seven strategies indicated that due to climate change, consumers would increase their demand for cool climates, geo-tourism, responsible travel, and “carbon offsetting” travel. In addition, these strategies identified that tourists may prefer environmentally friendly products, carbon offset schemes and "ethical” destinations that offer biodiversity conservation, renewable energy and visitor interpretation on the effects of climate change. For example, citing international research, TCCS_41:

“... geo-tourism and responsible travel are emerging as a world-wide cultural phenomenon, with an increasing ability to influence the consumer's choice in 
visitor destinations.” (Huon Valley Council, 2007, p. 51).

Just five of the 99 strategies identified that tourism contributes to climate change, which represents $1 \%$ of the entire sample of 477 . Four of these five strategies were produced in 2007 and 2008 when the Labor party was in power and promoting an emissions trading scheme. Thus, Australian tourism climate change strategies are most likely to be adaptation strategies rather than mitigation strategies (as they possibly do not recognise the need to mitigate). The five strategies that recognised the tourism industry's contribution to climate change mainly identified that transport can exacerbate climate change and that the "tourism industry is also a significant user of electricity and water” (TCCS_18: AECgroup, 2007, p. 107). This exact sentence was later repeated in TCCS_21 (Tourism Northern Territory, 2008, p. 36), revealing the diffusion of knowledge in the tourism strategic planning process and the truly limited acknowledgement of the tourism industry's contribution to climate change.

Ten strategies focused on Australia as a long-haul destination dependent on carbon-intensive air transport, which could be perceived by visitors as environmentally unfriendly. Two indicated that Australia's response to climate change could have a negative impact on "Brand Australia" and its international reputation, with Australia being "at risk of being seen as an environmentally unfriendly choice” (TCCS_8: Australian Government, 2009, p. 15). Climate change was cited as having the propensity to impact visitor comfort, safety and satisfaction. Eight strategies indicated that climate change would increase costs, specifically by raising insurance premiums, infrastructure upgrade, maintenance and relocation costs, health costs, electricity, gas and transport costs, and changing business financing. Further, it was identified that due to government policy reforms, "climate change will create compliance costs associated with government policy reforms” (TCCS_8: Australian Government, 2009, p. 15). Consequently, six strategies highlighted that failure to act on climate change over the long term would undermine the tourism industry's economic viability. This demonstrates a shift from mitigation to adaptation in tourism and climate change policy documents. TCCS_17 argued that:

\footnotetext{
“Tourism experts agree with the United Nations World Tourism Organisation that reducing travel is a simplistic response to climate change and fails to acknowledge the many benefits of tourism, both locally and globally” (Tourism Tasmania \& Tourism Industry Council Tasmania, 2007, p. 9).
} 
Table 1. Concepts within the issue identification theme

\begin{tabular}{ll}
\hline Climate change is a threat / issue / trend / challenge & 60
\end{tabular}

Forecasting or predicting climatic changes and impacts 37

Tourism is vulnerable to climate change $\quad 18$

Consumers focused on climate change and environmental sustainability 13

$\begin{array}{ll}\text { Australia is a long-haul destination } & 10\end{array}$

$\begin{array}{ll}\text { Long-term threat of climate change is a business risk } & 8\end{array}$

$\begin{array}{ll}\text { Climate change will increase costs } & 8\end{array}$

$\begin{array}{ll}\text { Consumers will demand different products and destinations } & 7\end{array}$

Australia’s natural environment and good climate are under threat $\quad 6$

$\begin{array}{ll}\text { Failure to act would undermine the tourism industry’s economic viability } & 6\end{array}$

Increased media and government attention on climate change $\quad 5$

Tourism contributes to climate change $\quad 5$

Australia’s response to climate change could impact its international reputation $\quad 2$

$\begin{array}{ll}\text { Climate change can impact visitor comfort, safety and satisfaction } & 1\end{array}$

Few businesses are sustainable or equipped to respond to and recover from crises $\quad 1$

Limiting/reducing travel is a simplistic response $\quad 1$

\section{Opportunities}

The climate change discourse also identified several opportunities arising from climate change. Twenty-six strategies noted that the tourism sector could develop innovative and new programs, experiences and products, such as implementing "carbon offset programs" (TCCS_18: AECgroup, 2007, p. 10), “green” business events and venues (e.g. TCCS_5), as well as bidding for conferences focused on sustainability, energy, the environment or climate change. In addition, the strategies also identified the opportunity to enhance existing tourism products by incorporating "climate change research and monitoring into conservation tourism initiatives” (TCCS_9: Australian Alps National Park, 2010, p. 32), becoming a research-based destination (e.g. TCCS_83). In addition, there was an opportunity to develop stories and heritage around climate change and conservation, as well as to "develop a product that is far less exposed to the likely impacts of climate change ...” (TCCS_18: AECgroup, 2007, p. 65). TCCS_27 also noted "there are opportunities for the industry in terms of increasing efficiency ... especially energy and waste” (South Australian Tourism Commission (SATC), 2009, p. 15).

Six strategies indicated that there was an opportunity to psychologically reposition current 
marketing and public relations with respect to tourism and climate change in key international visitor markets. The strategies suggested developing "green” destination marketing campaigns that showcase Australia's commitment to the environment and local communities and market Australia as a climate-friendly destination. Related to this, strategies indicated that the Australia.com website should present positive climate change-related marketing messages. The strategies proposed that marketing should target the emerging carbon conscious tourist. For example, TCCS_6 suggested “there are opportunities to reposition marketing strategies to adopt messages that address traveller concerns relating to climate change” (DRET, 2008, p. 11).

Sixteen of the 99 strategies indicated that Australia had an opportunity to leverage climate change action as a core point of market differentiation from other destinations. For example, TCCS_19 indicated that “Our vision is: Victoria will be recognised as the leading sustainable nature-based tourism destination in Australia ...” (Tourism Victoria, 2008, p. 7), which followed the exact sentiment of 16 other strategies, such as TCCS_69 which also stated a desire to be "the leading sustainable community in Australia" (Manly Council, 2006, p. 112). Notably, 10 of these 16 strategies were Destination Management Plans produced by Tourism Events Queensland in 2012. Three strategies also indicated that having a climate change strategy can offer a means to leverage resources.

\section{Table 2. Concepts within the opportunities theme}

\begin{tabular}{lr}
\hline Develop new or enhance existing tourism products & 26 \\
Become an environmental leader & 16 \\
Develop “green” destination marketing campaigns & 6 \\
Climate change strategy can leverage resources and reduce costs & 3 \\
Nature-based tourism and ecotourism & 2 \\
\hline
\end{tabular}

\section{Strategic needs}

Twenty strategies (20\%) identified further research into tourism and climate change as a key strategic need. Specifically, strategies identified a need for research that investigates "the costs and implications of climate change adaptation” (Tourism Transport Forum (TTF), 2006, p. 27) and that can accurately identify points of vulnerability in the tourism sector; for example, coastal erosion. The strategies also identified a need to understand the future impacts of "carbon 
prices and consumer demand patterns” (TCCS_8: Australian Government, 2009, p. 15), as well as the "economic impacts of climate change on tourism" (TCCS_6: DRET, 2008, p. 6). This type of research was highlighted as evidence is needed to identify areas of vulnerability and potential adaptation responses, and to inform strategic responses to climate change.

Thirteen strategies noted a need for the tourism industry to mobilise (using words like react, adapt and change) because of climate change, illustrating an awareness of adaptive strategies and resilience-based management. Strategies cited a need to innovate and to anticipate, adapt and act to address climate change impacts. Twelve strategies noted there is a need for longerterm planning that can respond to climate change. Seven strategies emphasised a need for risk and crisis management that focuses on preparation for business disruption, the availability of crises guides, and climate change response and contingency plans.

Ten strategies identified a need to respond by counteracting negative consumer perceptions and purchasing behaviours. Indeed, 38 (38\%) of the 99 Australian tourism climate change strategies identified the need to target high-yield but longer-staying market segments, compared with the 143 (29\%) of the 477 Australian tourism strategies. The strategies suggested that perceptions could be changed by reducing greenhouse gas emissions, bidding for conferences related to energy, sustainability, the environment and climate change, and focusing key government efforts on protecting vital tourism assets, such as the Great Barrier Reef. Six strategies argued there is a need to actively act to avoid dangerous climate change and protect vulnerable natural icons. Strategies cited a clear and urgent need to assist natural attractions deemed vulnerable to climate change, as well as government and industry connecting to combat potential issues surrounding tourism and climate change.

Four strategies argued for a "nationally consistent, inclusive, coordinated and cooperative approach” (TCCS_6: DRET, 2008, p. 5) to climate change policy implementation, specifically aimed at minimising and managing the impact tourism has on the environment and climate change. Two national strategies and a Northern Territory strategy released in 2008 suggested that tourism businesses need to have "green” policies and adopt different investment patterns or business models to remain competitive and viable in the face of climate change. These strategies suggested proactive action is required and that the tourism industry needs to become carbon neutral with programs and schemes (e.g. carbon offset schemes) that are credible and transparent with regular auditing and national regulation. 
Table 3. Concepts within the strategic needs theme

Research needed

Need for tourism to be adaptive and resilient

Need for longer-term planning / develop long-term strategies

Need to respond to counteract negative consumer perceptions and purchasing behaviours

Need for risk and crisis management

Need to actively work to avoid dangerous climate change and protect vulnerable natural icons

Businesses need to respond to changing consumer demands / behaviour

Need nationally consistent, inclusive, coordinated and cooperative approach to climate change

Need strategies to minimise and manage tourism impacts

Tourism businesses need to have "green" / sustainable policies and business models

Proactive action needed or aimed for

\section{Recommended strategies and actions}

Linked with the identified need for research, 24 strategies detailed different strategic frameworks, programs and tools with the potential to guide how the government and the tourism industry could measure, mitigate, reduce and offset its climate footprint and impacts. The strategies generally suggested minimising resource use through "solar panels, rainwater harvesting, insulation, wind power ... for climate change mitigation or adaptation” (Central NSW Tourism, 2013, p. 74). For example, the strategies suggested that tourism businesses should participate in recognised certification and accreditation schemes (e.g. GreenGlobe), as well as climate change and energy saving workshops where they could identify appropriate actions and priorities for climate change mitigation. Indeed, it was proposed that there should be "a single national accreditation program that offers easy and affordable compliance” (SATC, 2009, p. 17), as well as "a self-regulated voluntary Australian tourism climate change adaptation and carbon-offset scheme” (TTF, 2006, p. 58). The strategies proposed introducing new carbon measuring software systems (e.g. TCCS_5) and modelling the carbon footprint of the tourism industry and the impacts of climate change (e.g. TCCS_6). The strategies suggested spatial and vulnerability mapping (e.g. TCCS_88), as well as scenario planning to inform likely futures and adaptive management responses (e.g. TCCS_44).

Strategies highlighted within 16 documents focused on partnership and cooperation; the 
importance of trust. These strategies suggested partnership and collaboration to deal with climate change issues, specifically citing the need for ongoing constructive dialogue between the conservation and tourism sectors, different government departments, public and private sectors, different tourism businesses, tourism business leaders and climate change experts and across international borders. To achieve this, TCCS_25 suggested that tourism businesses should link with the Environmental Protection Agency's Carbon Innovators Network (Tourism Victoria, 2009, p. 21) highlighting the importance of such a network for multisectoral collaboration. However, while implemented and touted as a success by EPA Victoria (2010), in 2017 this network is no longer in existence. Twelve strategies highlighted the need for effective communication strategies allowing for the promotion of climate change action "to the market and more widely” (TCCS_6: DRET, 2008, p. 9).

Eleven strategies suggested that the government was focused on supporting tourism businesses to adopt climate change policy, prepare for a carbon constrained future and adapt their business model and manage climate change impacts, particularly by providing advice on climate change. The strategies suggested identifying programs to assist small businesses to adapt to climate change, manage risk, adjust economic activity, reduce vulnerability and improve investment certainty. It was indicated that government would support the development of high-quality interpretative material related to climate change (GBRMPA, 2009). It was also suggested tourism businesses could be engaged in climate change adaptation through CSIRO's Climate Change Adaptation project (Industry Resilience Working Group) (e.g. TCCS_11). Thirteen strategies focused on providing industry and stakeholder education and training designed to raise "community awareness of the potential effects of climate change on alpine environments and snow sports” (Tourism Victoria, 2009, p. 21), such as through the Keep Winter Cool initiative. Four strategies suggested developing incentives for undertaking climate change action and taking up new technologies (such as carbon-efficient next-generation aircraft) and certifications. For example, it was suggested that adapting businesses be given small grants and tax breaks (GBRMPA, 2009). In addition, it was proposed that industry awards recognising "green” initiatives should be implemented and that success stories could be showcased.

Five strategies suggested planning, managing and designing resilient sustainable destinations. These strategies suggested designing and investing in resilient infrastructure, facilities, amenities and accommodation that will maintain visitor satisfaction despite climate change and showcase the tourism industry’s "green” credentials (e.g. "climate-friendly” power generators, 
waste disposal systems, water conservation, alternative power or energy sources, and solar cities). Six strategies (three of which were state-level Victorian strategies) discussed the need for sustainability and climate adaptation strategies to become an overarching principle for the industry. These strategies argued that climate change policy should be integrated into all aspects of industry development and core business activities and be entrenched into regional and local level strategic planning. TCCS_25 highlighted that "particular attention is required in regional areas which are most affected by climate change” (Tourism Victoria, 2009, p. 15).

\section{Table 4. Concepts within the strategies theme}

Strategic framework for measuring, mitigating, reducing and offsetting climate footprint and impacts

Strategic partnerships and cooperation

Government and peak industry bodies to provide clear, accurate and consistent information

Education and training to foster awareness of the impacts of climate change and benefits of responding

Government to support tourism businesses to adopt climate change policy

Tourism businesses and destinations to demonstrate that they are adapting to climate change

Plan, manage and design resilient sustainable destinations

Sustainability and climate adaptation strategies to be the overarching principle for tourism

Develop incentives for undertaking climate change action and taking up new technologies / schemes

Develop heritage and cultural tourism as it is not as exposed to climate change

\section{Responding to climate change}

Eight strategies argued that tourism businesses are aware of climate change, are taking action and are "making an assertive effort to become "green" by reducing carbon footprints" (TCCS_4: Tourism Research Australia, 2008, p. 7). Seven strategies suggested that Australian governments are effectively using climate change policy for mitigation, business adaptation and protection of natural assets. Thus, it was argued that government is responding to climate change and that tourism climate change policy is being implemented. Examples offered to exemplify this included the establishment of the Queensland Climate Change Centre of Excellence, the development of a Queensland Climate Smart Adaptation Action Plan, the 
Queensland Greenhouse Strategy, the National Tourism Incident Response Plan, the National Tourism Investment Strategy, the Climate Change Adaptation Framework and the Climate Change Policy and Coordination Unit. Other examples were Tourism Victoria's Crisis Essentials and Open for Business: A Comprehensive Guide to Crisis Management for Tourism Business guides. In addition, strategies indicated that key performance indicators were now based on expenditure rather than visitor numbers.

Six strategies indicated that climate change policy is being implemented broadly at the international and national level, citing actions such as carbon taxing, the emissions trading scheme, carbon offsetting programs (e.g. TCCS_4), the Kyoto process (e.g. TCCS_6) and the Carbon Pollution Reduction Scheme (e.g. TCCS_25, TCCS_27 \& TCCS_44). Six strategies (all released prior to 2009 and three of which were at the national level) also indicated that consumers are participating in voluntary carbon offset schemes and reducing their carbon footprint, as evidenced by a rapidly growing carbon offset market.

Five strategies indicated that there are barriers to climate change adaptation and threats to adoption. Examples included the multitude of individual national parks, a lack of connectivity, cynicism regarding "commercial” offset programs, a lack of resources and capacity to manage threats posed by climate change, conflict between tourism and environmental activism/conservation groups and the fact that the industry will have no control over some aspects of climate change. Two strategies (TCCS_69 \& TCCS_23) argued that the government was not doing enough to combat climate change and had not delivered long-term solutions, citing further lobbying as having the potential to improve strategic initiatives.

\section{Table 5. Concepts within the evidence of response to climate change theme}

\begin{tabular}{lc}
\hline Tourism businesses are aware of climate change and are taking action and becoming “green” & 8 \\
Monitoring of strategies & 8 \\
Australian Government effectively using climate change policy & 7 \\
Climate change policy being implemented broadly & 6 \\
Consumers are adopting voluntary carbon offset schemes and reducing carbon footprint & 6 \\
Barriers to climate change adaptation / threats to adoption & 5 \\
Government has not delivered long-term solutions to climate change & 2
\end{tabular}




\section{Discussion}

This paper explored the climate change discourse in 477 Australian tourism policy documents across a 15-year period. The analysis showed that the discourse has increased and evolved significantly. There were tourism climate change policies apparent in all Australian states, with the majority produced at the regional and local level, revealing the importance of this globallocal issue (Kates \& Wilbanks, 2003). Yet, the results show that only 21\% of Australian tourism strategies (or 99 documents) mentioned climate change, of which there was primarily a focus on issue identification (69\%). Despite this, there were some that attempted to identify strategic needs (42\%) and recommend strategies and actions (42\%). There was a smaller proportion that highlighted the opportunities associated with climate change (33\%) and 20\% discussed responding to climate change, including the actions taken and the barriers/threats.

Following the UNWTO (2014) report, at the national level, climate change was not mentioned at all in the Australian Government's (2003) Tourism White Paper: A Medium to Long Term Strategy for Tourism; however, the National Tourism and Climate Change Taskforce in 2007 placed climate change firmly on the national tourism agenda from 2008 with Tourism and Climate Change - A Framework for Action. There was a significant increase in climate change discourse in the policy documents in the years that the Labor government was in power (20072013), particularly during the first term. Consequently, the National Long-term Tourism Strategy released in 2009 incorporated strategic discussion on climate change. Yet, by the 2011 update of the National Long-term Tourism Strategy: Tourism 2020, climate change had again been sidelined, with only one proposed action: engaging tourism businesses in adaptation.

Moreover, many of the Australian tourism strategies that did acknowledge climate change did not elaborate on the issue (e.g. Queensland's Destination Management Plans). Furthermore, the state level continues to lag on climate change policy, was underrepresented in the tourism climate change strategies and, conspicuously, New South Wales did not mention climate change in any state-level tourism strategies. Scott and Becken (2010) argue that building understanding about climate change and empowering stakeholders to act is the key to incorporating climate change strategies in tourism policy. However, it appears that the Australian tourism industry has failed to be "empowered" and to find solutions to climate change. Besides, with the decline in tourism strategies mentioning climate change in 2014, Australia's tourism industry has potentially fallen behind in the climate change debate, leaving the sector exposed to significant risk. While these findings may not be surprising to researchers 
working in the field, this research is important as it empirically demonstrates the lack of action and leadership available for Australia’s tourism sector to mitigate and adapt to climate change.

Another notable insight is that the strategies were overly focused on the impact of consumers' perceptions and responses to climate change, possibly because tourism organisations that produced the strategies believe that their only mandate is to provide marketing leadership. This confirms claims by Hall (2003), Ruhanen (2004, 2008) and Ruhanen, McLennan and Moyle (2013) that the Australian tourism industry tends to be preoccupied with marketing and shortterm tactical planning, rather than long-term strategic thinking. A growing concern about climate change among consumers represents both an opportunity and a threat to the tourism industry. The strategies revealed uncertainty about how to manage the risks and harnessing the opportunities of changing consumer perceptions and responses. While some strategies argued that tourism marketing campaigns should focus on developing "green” climate change-related marketing messages, others noted that growing climate change concern could negatively impact on Australia as a long-haul destination. Ruhanen and Shakeela (2013) also previously identified that the Australian tourism industry perceives climate change as a threat to Australia's appeal as a (long-haul) destination. This may be rhetoric of large inbound-focused industry players, which is not necessarily representative of the entire tourism industry in Australia (which is mostly reliant on domestic tourism). The true extent to which international tourism demand is subject to downturn due to visitor concern about carbon emissions is largely unknown and dependent on whether emissions reductions in long-haul travel can be achieved.

Our findings illustrate that, in some ways, the tourism industry is "playing the victim" and failing to plan for the long-term issue of climate change. Only five Australian tourism strategies, just $1 \%$ of the entire sample, recognised that tourism contributes to climate change. Indeed, four of these were produced when the Labor government was in power and promoting an emissions trading scheme. Moreover, the diffusion of the sentiment that tourism contributes to climate change has been narrowly clustered in a few closely related strategies. Consequently, with little acknowledgement of its own impact, the Australian tourism strategies have increasingly focused on adaptation strategies, to the detriment of mitigation strategies. To highlight this, consider the strength of the strategic discourse on voluntary carbon offsetting, which abruptly ceased in 2009. Prior to 2009, the strategies indicated that consumers were uptaking the schemes and that there was a rapidly growing carbon offset market. However, as noted by McLennan, Becken, Battye and So (2014), just 2.1\% of international visitors to Australia were offsetting in 2008, 2.7\% in 2009 and 2.5\% in 2010, with the only significant 
difference being between 2008 and 2009. After the carbon offsetting schemes ceased to be strategically promoted, the growth in uptake of offset schemes declined and the policy documents shifted from mitigation to adaptation strategies.

Consequently, there is evidence in this analysis to suggest that mitigation may have fallen off the tourism sector's climate change policy agenda. This aligns with McKercher et al. (2010) and Kaján and Saarinen (2013) who argue adaptation has become more prominent, with mitigation being superseded in both practice and scholarly discourse. Indeed, mitigation is a difficult response for tourism, as it makes a destination relatively more expensive, less competitive compared with other destinations and reduces the disposable income of the domestic tourism market (UNWTO, 2014). The tourism industry must be careful to fully acknowledge its impact on climate change and ensure appropriate mitigation policies are being implemented in addition to adaptation measures. In many ways, even tools such as certification and accreditation schemes (e.g. GreenGlobe) are essentially being viewed by industry as adaptation, rather than mitigation measures by focusing on reducing climate change induced costs (e.g. rising electricity bills) rather than mitigating their impact (McLennan et al., 2016).

The climate change discourse showed evidence of classic tourism rhetoric focused on "spinning" climate change to be a point of market differentiation, indicating that the tourism industry needs to promote its "green” credentials. Yet there were 16 Australian tourism climate change strategies that stated they wanted to be the "leading" sustainable destination in Australia. The strategies also argued that tourism businesses are aware of climate change and are acting, purporting to be effectively implementing climate change policy. Yet several strategies noted a need for the tourism industry to mobilise, as well as gain a greater awareness and uptake of adaptive strategies and plans and a need for longer-term planning for climate change. Moreover, the strategies identified further research into tourism and climate change as the primary strategic need, which shows a lack of understanding about how to respond.

The immaturity of the tourism industry's climate change policies is reflected in the uncoordinated approaches proposed by the policy documents. Indeed, 24 strategies detailed varying strategic frameworks, programs and tools that could be used to measure, mitigate, reduce and offset climate change, with little consistency. This highlights that the different levels of government plan in silos. Several strategies recognised this barrier, placing emphasis on the need for coordination, partnership, cooperation, trust and ongoing constructive dialogue cross-institutionally. Yet many strategies proposed to assist with this barrier have since ceased 
to exist (e.g. the Carbon Innovators Network, the STCRC). Moreover, many other initiatives proposed by the strategies and subsequently implemented have now ceased to exist (e.g. The Climate Change Adaptation project (Resilience Working Group), the Keep Winter Cool initiative, the Climate Change Action Fund, the Queensland Climate Change Centre of Excellence, and the Climate Change Policy and Coordination Unit (Northern Territory)).

Notably, the strategies did not mention the National Climate Change Adaptation Research Facility (established in 2008), which aims to support decision-makers in Australia prepare for and manage the risks of climate change. This indicates that the tourism industry is unaware of, and not well connected to, programs for climate change adaptation, particularly those promoted by the academic community. Other initiatives to assist adoption by businesses have also ceased or been scaled back (e.g. solar energy rebates), while the proposal to develop carbon-efficient next-generation aircraft is still yet to be realised. Carbon offsetting is still in place among some industry players (e.g. Qantas and Virgin Australia), but it is no longer a focus in the strategies. The proposal that key performance indicators should be based on expenditure, rather than visitation, has been implemented and remains a focus, but is problematic as increasing expenditure ultimately results in decision-makers aiming to increase visitor numbers.

The fact that so many of these initiatives have ceased to exist shows the extremely dynamic climate change policy environment, but also the lack of long-term consistent support for the tourism industry adaptation. Indeed, some strategies indicated that the government was not doing enough to combat climate change and had not delivered long-term solutions. This follows conclusions of Ruhanen and Shakeela (2013) that tourism businesses are unresponsive to climate change and operating as "business as usual" with a short-term outlook, despite climate change being perceived as high importance for the industry. But most importantly, the results indicate that Australia's tourism industry fails to recognise the broader connection between the issues faced by the industry and by the rest of the community. Beyond the tourism industry, many other industries are grappling with similar issues about how to adapt to these long-run trends (Garnaut, 2008). The tourism industry could learn from strategies and best practices applied in other industries (Hodgkinson, Hobday, \& Pinkard, 2014). On a regional level, it is vital to calibrate climate change strategies to the structure of local decision-making bodies and stakeholder participation programs found in cities and regions (Hunt \& Watkiss, 2011). Realising greater synergy between policymakers' climate change adaptation strategies and other policy priorities that are in the interests of consumers and businesses may help 
improve the implementation of climate change policy in the tourism sector.

\section{Conclusion, implications and future research}

This research conducted content and bibliometric analysis of the strategic discourse relating to climate change in Australia's national, state, regional and local tourism policy and planning documents over a 15-year period (2000-2014). Only 21\% of the documents mentioned climate change, with the focus of these being primarily on issue identification. While some policies developed strategies to address the long- and short-term implications of climate change, others simply paid "lip-service" to the topic. Despite the discourse remaining rooted in issue identification, encouragingly the results show that the policy discourse, particularly since 2008, has opened to identify opportunities, strategic needs, strategies and actions and identification of barriers and awareness of the broader challenges of climate change.

Our results, like that of the UNWTO (2014) report, revealed that the fluctuations in climate change policy implementation appears to be influenced by election cycles at the federal level. Perhaps long-term climate change strategies could be made more robust by building broader consensus and bipartisan approaches. Research evaluating the effectiveness of national climate change strategies (Biesbrock et al., 2010) suggested that robust communication strategies that convey key messages across partisan political lines are necessary. Consequently, two key questions arise from this research: 1) how should the industry operate under political uncertainty and in a dynamic climate change policy environment? and, 2) how should the tourism industry best leverage its limited resources to tackle climate change?

Finally, as policy is a process, it should not be confined to just policy documents, but instead should consider the broader policymaking environment, stakeholders and policy mechanisms, power and interest dynamics, and policy gaps. Consequently, future studies should focus on these areas to provide a complete understanding of climate change policy for tourism (Klint et al., 2012). Further research could focus on better understanding the diffusion process of climate change policies and whether it is government or industry driving adaptation and adoption of purported strategies. In addition, future research could expand the present study to investigate policy documents of other industries, to compare how different industries are preparing for climate change and to identify any implications for the tourism sector. This paper is a valuable resource for scholars seeking to discern key areas of potential intervention that require future research, as well as for those seeking to undertake cross-country or cross-sectoral comparisons. 


\section{References}

Adger, N. W., Arnell, N. W., \& Tompkins, E. L. (2005). Successful adaptation to climate change across scales. Global Environmental Change, 15(2), 77-86.

Airey, D., \& Ruhanen, L. (2013). Tourism policy-making in Australia. In: J. Fountain \& K. Moore (Eds), CAUTHE 2013: Tourism and global change: On the edge of something big. Christchurch, N.Z.: Lincoln University, 2013: 4-6. Retrieved from http://search.informit.com.au/documentSummary; $\mathrm{dn}=512446531557892 ;$ res=IELBUS

Angus, D., Rintel, S., \& Wiles, J. (2013). Making sense of big text: A visual-first approach for analysing text data using Leximancer and Discursis. International Journal of Social Research Methodology, 16(3), 261-267.

Australian Government (2003) Tourism White Paper: A Medium to Long Term Strategy for Tourism. Canberra, Australia: Commonwealth of Australia.

Becken, S. (2002). Analysing international tourist flows to estimate energy use associated with air travel. Journal of Sustainable Tourism, 10(2), 114-131.

Becken, S. (2013). A review of tourism and climate change as an evolving knowledge domain. Tourism Management Perspectives, 6, 53-62.

Becken, S., \& Hay, J. E. (2013). Climate change and tourism: From policy to practice. New York: Routledge.

Biesbroek, G. R., Swart, R. J., Carter, T. R., Cowan, C., Henrichs, T., Mela, H., ... \& Rey, D. (2010). Europe adapts to climate change: comparing national adaptation strategies. Global Environmental Change, 20(3), 440-450.

Bradley, E. H., Curry, L. A., \& Devers, K. J. (2007). Qualitative data analysis for health services research: Developing taxonomy, themes, and theory. Health Services Research, 42(4), 17581772.

Bulkeley, H. (2000). Discourse coalitions and the Australian climate change policy network. Environment and Planning C: Government and Policy, 18(6), 727-748.

Buultjens, J. White, N., \& Willacy, S. (2007). Climate Change and Australian Tourism: A Scoping Study. Gold Coast, Australia: Sustainable Tourism Cooperative Research Centre.

Buys, L., Miller, E., \& van Megen, K. (2012). Conceptualising climate change in rural Australia: community perceptions, attitudes and (in)actions. Regional Environmental Change, 12(1), 237-248.

Crowley, K., \& Coffey, B. (2007). Tasmania together and growing Victoria together: Can state plans deliver environmental sustainability? Public Administration Today, 10, 48-60.

Davoudi, S., Crawford, J., \& Mehmood, A. (Eds.). (2009). Planning for climate change: Strategies for mitigation and adaptation for spatial planners. London: Earthscan.

Dredge, D., \& Jenkins, J. M. (2007). Tourism planning and policy. Milton: John Wiley \& Sons.

Dwyer, L., Forsyth, P., Spurr, R., \& Hoque, S. (2010). Estimating the carbon footprint of Australian tourism. Journal of Sustainable Tourism, 18(3), 355-376.

EPA Victoria (2010). Concise annual report 2010: Transforming into a modern regulator. Melbourne: Victorian Government. Retrieved from http://www.epa.vic.gov.au/ /media/Publications/FINAL_Concise_Annual_Report2010_1352. pdf

Eton, D. T., Elraiyah, T. A., Yost, K. J., Ridgeway, J. L., Johnson, A., Mullan, R. J., Murad, M.H., Erwin, P.J., \& Montori, V. M. (2013). A systematic review of patient-reported measures of burden of treatment in three chronic diseases. Patient Related Outcome Measures, 5(4), 7-20.

Forsyth, P., Dwyer, L., \& Spurr, R. (2007). Climate change policies and Australian tourism: Scoping study of the economic aspects. Gold Coast, Australia: Sustainable Tourism Cooperative Research Centre.

Garnaut, R. (2008). The Garnaut climate change review. Cambridge: Cambridge University.

Goklany, I. M. (2003). Chapter 3: Climate change: The $21^{\text {st }}$ century's most urgent environmental problem or proverbial last straw? In K. Okonski (Ed.), Adapt or die: The science, politics and economics of climate change, pp. 56-74. London: Profile Books.

Gössling, S. (2010). Carbon management in tourism: Mitigating the impacts on climate change. London: Routledge. 
Gössling, S. (2013). National emissions from tourism: An overlooked policy challenge? Energy Policy, 59, 433-442.

Gössling, S., \& Hall, C. M. (2008). Swedish tourism and climate change mitigation: An emerging conflict? Scandinavian Journal of Hospitality and Tourism, 8(2), 141-158.

Hall, C. M. (2003). Introduction to tourism: Dimensions and issues (4th ed.). Frenchs Forest: Pearson Education Australia.

Hall, C. M., \& Jenkins, J. M. (1995). Tourism and public policy. London: Routledge.

Hall, C. M., \& Valentin, A. (2005). Content analysis. In B. W. Ritchie, P. Burns \& C. Palmer (Eds.), Tourism Research Methods: Integrating Theory with Practice. Cambridge: Cabi.

Hodgkinson, J. H., Hobday, A. J., \& Pinkard, E. A. (2014). Climate adaptation in Australia's resource-extraction industries: Ready or not? Regional Environmental Change, 14(4), 16631678.

Howlett, M. (2014). Why are policy innovations rare and so often negative? Blame avoidance and problem denial in climate change policy-making. Global Environmental Change, 29, 395403.

Hunt, A., \& Watkiss, P. (2011). Climate change impacts and adaptation in cities: a review of the literature. Climatic Change, 104(1), 13-49.

Kaján, E., \& Saarinen, J. (2013). Tourism, climate change and adaptation: a review. Current Issues in Tourism, 16(2), 167-195.

Kates, R. W., \& Wilbanks, T. J. (2003). Making the global local responding to climate change concerns from the ground. Environment: Science and Policy for Sustainable Development, 45(3), 12-23.

Klint, L. M., Wong, E., Jiang, M., Delacy, T., Harrison, D., \& Dominey-Howes, D. (2012). Climate change adaptation in the Pacific Island tourism sector: analysing the policy environment in Vanuatu. Current Issues in Tourism, 15(3), 247-274.

McKercher, B., Prideaux, B., Cheung, C., \& Law, R. (2010). Achieving voluntary reductions in the carbon footprint of tourism and climate change. Journal of Sustainable Tourism, 18(3), 297317.

McLennan, C. J., Becken, S., Battye, R., \& So, K. K. F. (2014). Voluntary carbon offsetting: Who does it? Tourism Management, 45, 194-198.

McLennan, C. J., Becken, S., \& Watt, M. (2016). Learning through a cluster approach: lessons from the implementation of six Australian tourism business sustainability programs. Journal of Cleaner Production, 111(Part B), 348-357.

McMahon, L., \& Phillimore, J. (2013). State and territory government strategic plans: Exercises in Managing, monitoring and marketing. Australian Journal of Public Administration, 72(4), 404-418.

Mercer, D., \& Marden, P. (2006). Ecologically sustainable development in a 'quarry' economy: One step forward, two steps back. Geographical Research, 44(2), 183-203.

Morrison, C., \& Pickering, C. M. (2013). Perceptions of climate change impacts, adaptation and limits to adaption in the Australian Alps: the ski-tourism industry and key stakeholders. Journal of Sustainable Tourism, 21(2), 173-191.

Moyle, B. D., McLennan, C. J., Ruhanen, L., \& Weiler, B. (2014). Tracking the concept of sustainability in Australian tourism policy and planning documents. Journal of Sustainable Tourism, 22(7), 1037-1051.

Mukheibir, P., Kuruppu, N., Gero, A., \& Herriman, J. (2013). Overcoming cross-scale challenges to climate change adaptation for local government: A focus on Australia. Climatic Change, 121(2), 271-283.

Parliament of NSW. (2017). The Roles and Responsibilities of Federal, State and Local Governments. Accessed 7 July 2017. Retrieved from https://www.parliament.nsw.gov.au/about/Pages/TheRoles-and-Responsibilities-of-Federal-State-a.aspx

Perch-Nielsen, S., Sesartic, A., \& Stucki, M. (2010). The greenhouse gas intensity of the tourism sector: The case of Switzerland. Environmental Science \& Policy, 13(2), 131-140.

Peters, G. P., Andrew, R. M., Canadell, J. G., Fuss, S., Jackson, R. B., Korsbakken, J. I., ... \& Nakicenovic, N. (2017). Key indicators to track current progress and future ambition of the Paris Agreement. Nature Climate Change, 7(2), 118-122. 
Pforr, C. (2015). Tourism public policy in pursuit of sustainability: Discrepancies between rhetoric and reality. In M. Hughes, D. Weaver \& C. Pforr (Eds.), The practice of sustainable tourism: Resolving the paradox, pp. 24-37. United Kingdom: Routledge.

Pforr, C., \& Brueckner, M. (2012). Tourism strategy through partnership: Rhetoric or reality? A case example from Australia. Proceedings of the International Conference on Tourism: Tourism in an Era of Uncertainty, Greece.

Phillips, H., \& Kerr, L. (2005). Western Australia. Australian Journal of Politics \& History, 51(2), 297-302.

Rosselló-Nadal, J. (2014). How to evaluate the effects of climate change on tourism. Tourism Management, 42, 334-340.

Ruhanen, L. (2004). Strategic planning for local tourism destinations: An analysis of tourism plans. Tourism and Hospitality: Planning and Development, 1(3), 239-253.

Ruhanen, L. (2008). Progressing the sustainability debate: A knowledge management approach to sustainable tourism planning. Current Issues in Tourism, 15(5), 429-455.

Ruhanen, L., McLennan, C., \& Moyle, B. (2013). Strategic Issues in the Australian tourism industry: A 10-year analysis of national strategies and plans. Asia Pacific Journal of Tourism Research, 18(3), 220-240.

Ruhanen, L., Weiler, B., Moyle, B. D., \& McLennan, C. J. (2015). Trends and patterns in sustainable tourism research: A 25-year bibliometric analysis. Journal of Sustainable Tourism, 23(4), 517-535.

Ruhanen, L., \& Shakeela, A. (2013) Responding to climate change: Australian tourism industry perspectives on current challenges and future directions, Asia Pacific Journal of Tourism Research, 18(1-2), 35-51.

Ruhanen, L., Breakey, N., \& Robinson, R. (2012). Knowledge exchange and networks: A new destination for tourism internships? Current Issues in Tourism, 15(3), 183-196.

Scott, D., \& Becken, S. (2010). Adapting to climate change and climate policy: Progress, problems and potentials. Journal of Sustainable Tourism, 18(3), 283-295.

Scott, D., Hall, C. M., \& Gössling, S. (2016). A report on the Paris Climate Change Agreement and its implications for tourism: Why we will always have Paris. Journal of Sustainable Tourism, 24(7), 933-948.

Shakeela, A., \& Becken, S. (2015). Understanding tourism leaders' perceptions of risks from climate change: an assessment of policy-making processes in the Maldives using the social amplification of risk framework (SARF). Journal of Sustainable Tourism, 23(1), 65-84.

Taberner, J., \& Zorzetto, J. (2014). A short history of climate change policy in Australia. Australian Environmental Law Digest, 1(2), 1-16.

Talberg, A., Hui, S., \& Loynes, K. (2016). Australian climate change policy to 2015: a chronology. Research Paper Series 2015-16. Parliament of Australia, Canberra.

Turton, S., Dickson, T., Hadwen, W., Jorgensen, B., Pham, T., Simmons, D., Tremblay, P., \& Wilson, R. (2010). Developing an approach for tourism climate change assessment: Evidence from four contrasting Australian case studies. Journal of Sustainable Tourism, 18(3), 429-447.

United Nations World Tourism Organisation [UNWTO] (2014). Chapter 7: Twenty-five years of Australian federal climate change policy: implications for tourism. In Responding to Climate Change: Tourism Initiatives in Asia and the Pacific. Retrieved from http://publications.unwto.org/publication/responding-climate-change-tourism-initiatives-asiaand-pacific

Van Dijk, P. A., \& Kirk, A. (2007). Being somebody else: Emotional labour and emotional dissonance in the context of the service experience at a heritage tourism site. Journal of Hospitality and Tourism Management, 14(2), 157-169.

Vogel, B., \& Henstra, D. (2015). Studying local climate adaptation: A heuristic research framework for comparative policy analysis. Global Environmental Change, 31, 110-120.

Wilson, E. (2006). Adapting to climate change at the local level: The spatial planning response, Local Environment, 11(6), 609-625. 


\section{Appendix A. List of included Australian tourism climate change strategies}

\begin{tabular}{|c|c|c|c|c|}
\hline $\begin{array}{l}\text { Strategy } \\
\text { no. }\end{array}$ & $\begin{array}{l}\text { Policy } \\
\text { level }\end{array}$ & Organisation & Strategy & $\begin{array}{l}\text { Date of } \\
\text { article }\end{array}$ \\
\hline 1 & National & Tourism Transport Forum & $\begin{array}{l}\text { Natural Tourism Partnerships: Action Plan. Creating effective public-private partnerships } \\
\text { for natural tourism and conservation in Australian Parks }\end{array}$ & 2006 \\
\hline 2 & National & Indigenous Tourism Australia & National Strategy for Indigenous Tourism 2007-2012 & 2007 \\
\hline 3 & National & Winemakers Federation of Australia & Wine Australia: Directions to 2025 & 2007 \\
\hline 4 & National & Tourism Research Australia & Through the looking glass: the future of domestic tourism in Australia & 2008 \\
\hline 5 & National & The Business Events Industry Strategy Group & A National Business Events Strategy for Australia 2020 & 2008 \\
\hline 6 & National & $\begin{array}{l}\text { Department of Resources, Energy and } \\
\text { Tourism }\end{array}$ & Tourism and Climate Change - A Framework for Action & 2008 \\
\hline 7 & National & $\begin{array}{l}\text { Australian Government, Department of } \\
\text { Resources, Energy and Tourism }\end{array}$ & National Long-term Tourism Strategy & 2009 \\
\hline 8 & National & $\begin{array}{l}\text { Australian Government and the National } \\
\text { Long-term Tourism Strategy Steering } \\
\text { Committee }\end{array}$ & The Jackson Report: Informing the National Long-term Tourism Strategy & 2009 \\
\hline 9 & National & Australian Alps National Park & $\begin{array}{l}\text { Australian Alps National Landscape Tourism Strategy for the international Experience } \\
\text { Seeker Market }\end{array}$ & 2010 \\
\hline 10 & National & $\begin{array}{l}\text { Department of Resources, Energy and } \\
\text { Tourism }\end{array}$ & National Long-term Tourism Strategy Progress Report & 2011 \\
\hline 11 & National & $\begin{array}{l}\text { Department of Resources, Energy and } \\
\text { Tourism }\end{array}$ & National Long-term Tourism Strategy - Tourism 2020 & 2011 \\
\hline 12 & State & Tourism Victoria & The Significance of Tourism Strategic Plan 2002-2006 & 2002 \\
\hline 13 & State & $\begin{array}{l}\text { Department of Tourism, Fair Trading and } \\
\text { Wine Industry Development, Tourism } \\
\text { Queensland }\end{array}$ & Queensland Wine Industry Development Strategy & 2004 \\
\hline 14 & State & $\begin{array}{l}\text { Victoria Tourism Industry Council and } \\
\text { Victoria Events Industry Council }\end{array}$ & Tourism and Events Strategy 2016 & 2006 \\
\hline 15 & State & Tourism Victoria & Tourism Victoria Business Plan 2008-2011 & 2007 \\
\hline 16 & State & Tourism Western Australia & Strategic Plan 2008 to 2013: building for the future & 2007 \\
\hline 17 & State & $\begin{array}{l}\text { Tourism Tasmania, Tourism Industry Council } \\
\text { Tasmania }\end{array}$ & Tourism 21: Strategic Business Plan 2007-2010 & 2007 \\
\hline 18 & State & AECgroup & Strategic Plan for the NT Tourism Industry: Recommendations of the AECgroup & 2007 \\
\hline 19 & State & Tourism Victoria & Victoria's Nature-based Tourism Strategy 2008-2012 & 2008 \\
\hline
\end{tabular}




\begin{tabular}{|c|c|c|c|c|}
\hline 20 & State & $\begin{array}{l}\text { Queensland Government, Tourism } \\
\text { Queensland, Queensland Tourism Industry } \\
\text { Council }\end{array}$ & Queensland Tourism Strategy & 2008 \\
\hline 21 & State & Tourism Northern Territory & $\begin{array}{l}\text { Five Year Tourism Strategic Plan: A plan to guide the direction and success of the } \\
\text { Northern Territory tourism industry } 2008 \text { to } 2012\end{array}$ & 2008 \\
\hline 22 & State & Tourism Victoria & Backpacker Tourism Action Plan 2009-2013 & 2009 \\
\hline 23 & State & Tourism Victoria & Victoria's Golf Tourism Action Plan 2009-2012 & 2009 \\
\hline 24 & State & Tourism Victoria & Regional Tourism Action Plan 2009-2012 & 2009 \\
\hline 25 & State & Tourism Victoria & Environmentally Sustainable Tourism Strategic Plan 2009-2012 & 2009 \\
\hline 26 & State & South Australian Tourism Commission & South Australian Food and Wine Tourism Strategy 2009-2014 & 2009 \\
\hline 27 & State & South Australian Tourism Commission & South Australian Tourism Plan 2009-2014 & 2009 \\
\hline 28 & State & Tourism Northern Territory & Five Year Tourism Strategic Plan 2009 Industry Update & 2009 \\
\hline 29 & State & Australian Capital Tourism & Five Year strategic plan 2009-13 & 2009 \\
\hline 30 & State & Queensland Government & Tourism Industry Sector Action Plan & 2006 \\
\hline 31 & Regional & Tourism Queensland & Brisbane Destination Management Plan & 2004 \\
\hline 32 & Regional & Tourism Queensland & Sunshine Coast Destination Management Plan & 2004 \\
\hline 33 & Regional & NSW Government Department of Planning & Illawarra and South Coast Regional Strategies & 2005 \\
\hline 34 & Regional & $\begin{array}{l}\text { Queensland Government Office of Urban } \\
\text { Management }\end{array}$ & South East Queensland Regional Plan 2005-2026 & 2005 \\
\hline 35 & Regional & Tourism Queensland & Gold Coast Destination Management Plan & 2005 \\
\hline 36 & Regional & Kakadu National Park & Kakadu National Park Management Plan 2007-2014 & 2007 \\
\hline 37 & Regional & Tourism Queensland & Destination Management Plan for Tourism in South East Queensland Country & 2007 \\
\hline 38 & Regional & Tourism Queensland & Destination Management Plan for Tourism in the Fraser Coast 2007-2010 & 2007 \\
\hline 39 & Regional & Tourism Tropical North Queensland & Tourism Research Needs Analysis & 2007 \\
\hline 40 & Regional & $\begin{array}{l}\text { Alexandrina Council, District Council of } \\
\text { Yankalilla, City of Onkaparinga, City of } \\
\text { Victor Harbor, South Australian Tourism } \\
\text { Commission }\end{array}$ & Fleurieu Peninsula Region Integrated Strategic Tourism Plan 2007-2012 & 2007 \\
\hline 41 & Regional & $\begin{array}{l}\text { Huon Valley Council, Tourism Tasmania and } \\
\text { Totally South Tourism }\end{array}$ & $\begin{array}{l}\text { Far South Tasmania Tourism Development Strategy: For the region from Dover to Cockle } \\
\text { Creek }\end{array}$ & 2007 \\
\hline 42 & Regional & Tourism Tropical North Queensland & Tourism Industry Research Needs Analysis - Great Barrier Reef Region & 2008 \\
\hline 43 & Regional & Northern Rivers Tourism & Northern Rivers Tourism Strategic Plan 2009-2011 & 2009 \\
\hline 44 & Regional & Great Barrier Reef Marine Park Authority & Great Barrier Reef Tourism Climate Change Action Strategy 2009-2012 & 2009 \\
\hline 45 & Regional & $\begin{array}{l}\text { Department of Natural Resources, } \\
\text { Environment, the Arts and Sport }\end{array}$ & West MacDonnell (Tyurretye) National Park Joint Management Plan 2009 -DRAFT & 2009 \\
\hline
\end{tabular}




\begin{tabular}{|c|c|c|c|c|}
\hline 46 & Regional & Mid North Coast Tourism & Mid North Coast Tourism Strategic Business and Marketing Plan 2010-2011 & 2010 \\
\hline 47 & Regional & Uluru-Kata Tjuta Board of Management & Uluru-Kata Tjuta National Park Management Plan 2010-2020 & 2010 \\
\hline 48 & Regional & $\begin{array}{l}\text { Regional Development Australia \& NSW } \\
\text { Department of Trade and Investment }\end{array}$ & Regional Development in the Far West NSW Region & 2011 \\
\hline 49 & Regional & Yorke Peninsula Tourism & Yorke Peninsula Regional Strategic Tourism Plan 2011-2014 & 2011 \\
\hline 50 & Regional & Regional Development Australia & Southern Inland 5-year plan: 2012-2017 & 2012 \\
\hline 51 & Regional & Tourism Queensland & Gold Coast Destination Tourism Strategy 2012-2016 & 2012 \\
\hline 52 & Regional & Tourism Queensland & Sunshine Coast Destination Tourism Strategy 2012-2016 & 2012 \\
\hline 53 & Regional & Tourism Queensland & Fraser Coast Destination Tourism Strategy 2012 - 2016 & 2012 \\
\hline 54 & Regional & Tourism Queensland & Bundaberg North Burnett Region Destination Tourism Strategy 2012-2016 & 2012 \\
\hline 55 & Regional & Tourism Queensland & Gladstone Region Destination Tourism Strategy 2012-2016 & 2012 \\
\hline 56 & Regional & Tourism Queensland & Destination Tourism Strategy Mackay Region 2012 - 2016 & 2012 \\
\hline 57 & Regional & Tourism Queensland & Tropical North Queensland Destination Tourism Strategy $2012-2016$ & 2012 \\
\hline 58 & Regional & Tourism Queensland & Outback, Gulf and Western Downs Region Destination Tourism Strategy 2012 - 2016 & 2012 \\
\hline 59 & Regional & Tourism Snowy Mountains & Snowy Mountains Destination Management Plan & 2013 \\
\hline 60 & Regional & Central NSW Tourism & Central NSW Destination Management Plan & 2013 \\
\hline 61 & Regional & $\begin{array}{l}\text { Department of Infrastructure, energy and } \\
\text { resources }\end{array}$ & Northern Integrated Transport Plan 2013 & 2013 \\
\hline 62 & Regional & Sapphire Coast Tourism & Sapphire Coast Destination Management Plan & 2014 \\
\hline 63 & Regional & Tourism Queensland & Destination Management Plan for Tourism in Queensland's Outback & N/A \\
\hline 64 & Local & Tourism Queensland & Whitsundays Destination Management Plan & 2004 \\
\hline 65 & Local & Tourism Queensland & Townsville Destination Management Plan & 2004 \\
\hline 66 & Local & Greater Bendigo City Council & City of Greater Bendigo Council Plan 2005-2009 & 2005 \\
\hline 67 & Local & Tourism Queensland & Tropical North Queensland Destination Management Plan & 2005 \\
\hline 68 & Local & Derwent Valley Council & Derwent Valley Council Strategic Plan 2005/2010 & 2005 \\
\hline 69 & Local & Manly Council & Manly Sustainability Strategy: For Today and Future Generations & 2006 \\
\hline 70 & Local & Ballarat City Council & City of Ballarat Economic Development Strategy 2006 & 2006 \\
\hline 71 & Local & Victor Harbour City Council & City of Victor Harbour: Strategic Directions 2006/2009 & 2006 \\
\hline 72 & Local & $\begin{array}{l}\text { Kangaroo Island Development Board, } \\
\text { Kangaroo Island Council, Tourism KI }\end{array}$ & Kangaroo Island Strategic Tourism Plan & 2006 \\
\hline 73 & Local & Dubbo City Council & Dubbo City Council Corporate Strategic Plan 2007-2027 & 2007 \\
\hline 74 & Local & Brisbane Marketing & Brisbane Destination Management Plan: Draft & 2007 \\
\hline 75 & Local & Tourism Queensland & Bundaberg Destination Management Plan & 2007 \\
\hline 76 & Local & Tourism Queensland & Destination Management Plan for Tourism in Central Queensland: Gladstone & 2007 \\
\hline
\end{tabular}




\begin{tabular}{|c|c|c|c|c|}
\hline 77 & Local & Tourism Queensland & Mackay Region Destination Management Plan 2007-2010 & 2007 \\
\hline 78 & Local & Tourism Queensland & Destination Management Plan for Tourism in Central Queensland: Capricorn & 2007 \\
\hline 79 & Local & Northern Areas Council & Northern Areas Council Strategic Plan 2007-2010 & 2007 \\
\hline 80 & Local & Mandurah City Council & Local Tourism Planning Strategy Draft & 2007 \\
\hline 81 & Local & Logan City Council & Logan City Economic Development Strategy 2008-2012 & 2008 \\
\hline 82 & Local & Sorell Council & Sorell Council: Community Strategic Plan 2008-2013 & 2008 \\
\hline 83 & Local & Rottnest Island Authority & Rottnest Island Management Plan 2009 - 2014 & 2009 \\
\hline 84 & Local & $\begin{array}{l}\text { Huon Valley Council, Department of } \\
\text { Resources, Energy and Tourism, } \\
\text { Kingsborough }\end{array}$ & Huon Valley Regional Tourism Strategy 2009 - 2012 & 2009 \\
\hline 85 & Local & Sapphire Coast Tourism \& EC3 Global & Sapphire Coast Heritage Tourism Strategy & 2010 \\
\hline 86 & Local & Mildura Tourism & Mildura Tourism 5 Year Strategic Plan 2010-2014 & 2010 \\
\hline 87 & Local & Southern Grampians Shire Council & Southern Grampians Shire Tourism Strategic Plan 2010-2015 & 2010 \\
\hline 88 & Local & Hobart City Council & H30 Hobart Capital City Plan 2011-2040: DRAFT & 2011 \\
\hline 89 & Local & Tourism Queensland, Capricorn Tourism & Capricorn Region Destination Tourism Strategy 2012-2016 & 2012 \\
\hline 90 & Local & Tourism Queensland & The Whitsundays Destination Tourism Strategy 2012-2016 & 2012 \\
\hline 91 & Local & Tourism Queensland & Townsville North Queensland Region Destination Tourism Strategy 2012-2016 & 2012 \\
\hline 92 & Local & Murraylands Tourism Partnerships & Murray River, Lakes \& Coorong Tourism Strategy and Action Plan 2012-13 to 2015-16 & 2012 \\
\hline 93 & Local & $\begin{array}{l}\text { Responsible Tourism \& Kangaroo Valley } \\
\text { Tourist Association }\end{array}$ & Kangaroo Valley Destination Management Plan 2013 & 2013 \\
\hline 94 & Local & Lithgow City Council \& NSW Government & Lithgow Destination Management Plan 2013 & 2013 \\
\hline 95 & Local & Kalamunda Shire Council & Kalamunda Advancing: Strategic Community Plan 2023 & 2013 \\
\hline 96 & Local & Ballina Shire Council & Destination Management Plan for the Ballina Coast \& Hinterland 2014-2020: DRAFT & 2014 \\
\hline 97 & Local & City of Whittlesea & Tourism Strategy 2014-2019 & 2014 \\
\hline 98 & Local & Adelaide Hills Council & Adelaide Hills Council Strategic management plan & N/A \\
\hline 99 & Local & CCS Strategic Management & Serpentine Jarrahdale Shire Community Facilities and Services Plan 2020 & N/A \\
\hline
\end{tabular}

